\title{
IMPLIKASI BENTUK HUKUM BUMD TERHADAP PENGELOLAAN BUMD THE IMPLICATION OF REGIONAL OWNED ENTERPRISES LEGAL FORM TO ITS MANAGEMENT
}

\author{
Dian Cahyaningrum \\ Pusat Penelitian Badan Keahlian DPR RI \\ Komplek MPR/DPR/DPD Gedung Nusantara 1 Lantai 2, \\ Jl. Jenderal Gatot Subroto Jakarta \\ Email: cahyaningrum@yahoo.com \\ Naskah diterima: 27 Maret 2018 \\ Naskah direvisi: 18 Mei 2018 \\ Naskah diterbitkan: 30 Juni 2018
}

\begin{abstract}
These days many regional owned enterprises are still low on the quality due to they are not well managed. The one of the matter it may be caused by the regional owned enterprises legal form. This scientific study intended to analyze the implication of the regional owned enterprises legal form to its management. Based on the results of the study, there are two legal forms of the regional owned enterprises. They are regional public company (Perumda) and regional liability company (Perseroda). The Perumda is oriented to the public service. However, the Perumda also have to gain some profit. While the Perseroda is oriented to profit. In order to achieve that goals, the Perumda and the Perseroda have to be managed well based on PP no 54 year 2017, beside that have to be supported by realiable human resources and enough capital. The organs of the Perumda and the Perseroda also should be professional in performing their duties. Other implication of the Perumda and the Perseroda are to the regional leader owned a big authority to establish the Perumda and the Perseroda regulation. It caused the regional leader's vision, mission, and good intention will determine the Perumda and the Perseroda development. The Perumda and the Perseroda will be able to develop well if the regional leader's vision, mission, and intention are good. Otherwise, the Perumda and the Perseroda will be difficult to develop. In order to develop the Perumda and the Perseroda, the regional leader should have a good vision, mission, faith and serious will to develop the Perumda and the Perseroda; The organs and the employer of the Perumda and the Perseroda should be well recruited based on PP no 54 year 2017; the organ of the Perumda and the Perseroda also should be independence in performing their duties without any intervention which is not in accordance with the law.
\end{abstract}

Key words: regional owned enterprises; regional public company (Perumda); regional liability company (Perseroda); director; regional leader

\begin{abstract}
Abstrak
Saat ini banyak BUMD yang berkualitas rendah karena belum dikelola dengan baik. Salah satu hal yang mempengaruhi pengelolaan BUMD adalah bentuk hukumnya. Untuk itu kajian ini menganalisa implikasi dari bentuk hukum BUMD terhadap pengelolaannya. Berdasarkan hasil kajian ada dua bentuk hukum BUMD yaitu Perumda dan Perseroda. Bentuk hukum Perumda berorientasi pada pelayanan umum. Namun Perumda juga harus mencari keuntungan. Sedangkan bentuk hukum Perseroda berorientasi pada mencari keuntungan. Agar tujuan tersebut tercapai, Perumda dan Perseroda harus dikelola dengan baik sesuai dengan PP No. 54 Tahun 2017, selain juga harus didukung dengan SDM yang handal dan modal yang memadai. Organ Perumda dan Perseroda juga harus profesional dalam menjalankan tugasnya. Implikasi lain dari Perumda dan Perseroda adalah kepala daerah memiliki kewenangan yang besar dalam menentukan kebijakan Perumda dan Perseroda. Akibatnya visi, misi, dan itikad baik kepala daerah menentukan
\end{abstract}


perkembangan Perumda dan Perseroda. Apabila kepala daerah memiliki visi, misi, dan itikad yang baik maka Perumda dan Perseroda dapat berkembang dengan baik. Namun jika sebaliknya, maka Perumda dan Perseroda akan sulit untuk berkembang. Agar Perumda dan Perseroda dapat dikelola dan berkembang dengan baik maka kepala daerah harus memiliki visi, misi, niat baik, dan keseriusan untuk mengembangkannya; organ dan pegawai Perumda dan Perseroda harus direkrut dengan benar sesuai PP No. 54 Tahun 2017; organ Perumda dan Perseroda juga harus memiliki kemandirian dan independensi dalam menjalankan tugasnya tanpa ada campur tangan dari siapa pun dan dalam bentuk apa pun yang tidak sesuai dengan ketentuan peraturan perundang-undangan.

Kata kunci: BUMD; Perumda; Perseroda; direksi; kepala daerah

\section{PENDAHULUAN}

Pengelolaan Badan Usaha Milik Daerah (BUMD) menjadi masalah yang mengemuka seiring dengan banyaknya BUMD yang kondisinya masih cukup memprihatinkan. Jika dilihat dari sisi kuantitas, perkembangan jumlah BUMD memang cukup menggembirakan. Berdasarkan hasil studi Biro Analisa Keuangan Kementerian Keuangan pada tahun 1997, pada masa sebelum adanya otonomi daerah tepatnya pada awal Pelita I, perkembangan BUMD secara kuantitatif tidak begitu pesat yaitu hanya ada sebanyak 122 BUMD. Jumlah tersebut meningkat menjadi 651 BUMD pada tahun $1996 .{ }^{1}$ Selanjutnya sebagaimana dikemukakan oleh Ketua Penyelenggara BUMD Business Summit 2014, Ahmad Zaidin, jumlah BUMD di seluruh Indonesia meningkat lebih dari 2 kali lipat pada tahun 2014 hingga mencapai 1700 BUMD. ${ }^{2}$ Peningkatan jumlah BUMD

\footnotetext{
Mandala Harefa, "Pengelolaan BUMD/Perusahaan Daerah di Provnsi Sumatera Barat, Nusa Tenggara Barat dan Kalimantan Selatan”, Kajian, Vol.15, No.2, Juni 2010, hal. 199-226.

Avit Hidayat, 17 Desember 2014, "1360 BUMD SeIndonesia Tidak Sehat”, http://www.enciety.co/1360-bumdse-indonesia-tidak-sehat/, diakses tanggal 20 April 2017.
}

tersebut seiring dengan adanya keinginan kuat dari pemerintah daerah di era otonomi daerah untuk mendirikan BUMD guna mengelola potensi daerah untuk meghasilkan pendapatan asli daerah (PAD), dan memberikan pelayanan kepada masyarakat di daerah yang bersangkutan.

Sayangnya kuantitas BUMD tersebut tidak diiringi dengan kualitas kinerjanya. Sebagaimana dikemukakan oleh Ahmad Zaidin, dari total 1.700 BUMD, sedikitnya 1.360 BUMD (80\% BUMD) masih tidak sehat. Kebanyakan BUMD di seluruh Indonesia masih mengandalkan Anggaran Pendapatan Belanja Daerah (APBD) untuk operasional perusahaan. Hanya 340 BUMD (20\% BUMD) yang sudah mandiri dan tidak membebani APBD masing-masing daerah. Ahmad Zaidin juga mengemukakan kualitas produksi BUMD masih jauh dari harapan sehingga masih kalah bersaing dengan perusahaan lain di ASEAN. ${ }^{3}$

Pendapat senada dikemukakan oleh Deputi Kepala Badan Pengawas Keuangan dan Pembangunan (BPKP) Bidang Akuntan Negara, Gatot Darmasto yang mengatakan sebanyak 1.477 BUMD/Badan Layanan Umum Daerah (BLUD) di seluruh Indonesia, mayoritas belum sehat dan sekitar lebih dari 80\% bermasalah di daerahnya sehingga belum bisa memberikan kontribusi ke APBD di daerahnya masing-masing. Jika ada profit, maka kontribusi ke APBD sangatlah kecil. ${ }^{4}$ BUMD yang ada selama ini belum mampu memberikan kontribusi yang signifikan terhadap pendapatan asli daerah (PAD), bahkan justru lebih banyak "suntikan" dana dari pemerintah daerah daripada keuntungan yang didapat sehingga membebani APBD. ${ }^{5}$ Begitupula

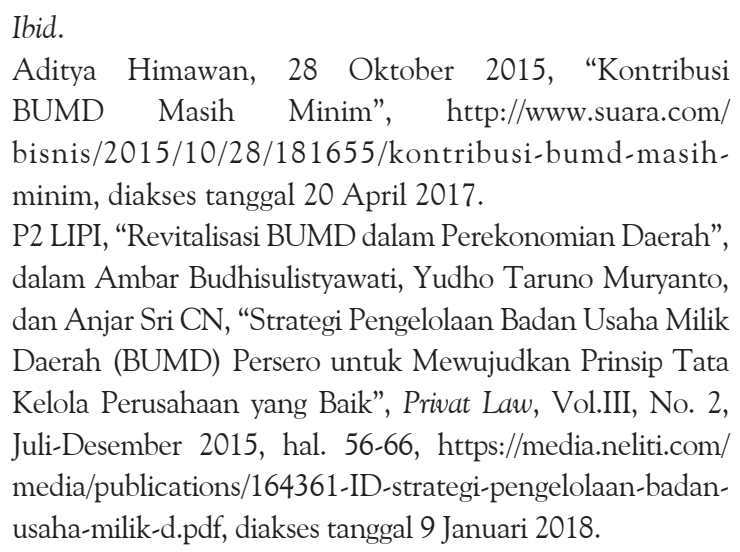
bisnis/2015/10/28/181655/kontribusi-bumd-masihminim, diakses tanggal 20 April 2017.

P2 LIPI, "Revitalisasi BUMD dalam Perekonomian Daerah", dalam Ambar Budhisulistyawati, Yudho Taruno Muryanto, dan Anjar Sri CN, "Strategi Pengelolaan Badan Usaha Milik Daerah (BUMD) Persero untuk Mewujudkan Prinsip Tata Kelola Perusahaan yang Baik", Privat Law, Vol.III, No. 2, Juli-Desember 2015, hal. 56-66, https://media.neliti.com/ media/publications/164361-ID-strategi-pengelolaan-badanusaha-milik-d.pdf, diakses tanggal 9 Januari 2018. 
beberapa pengamat, diantaranya Pengamat Ekonomi Universitas Islam Indonesia (UII), Suwarsono Muhammad juga mengemukakan buruknya kondisi BUMD di Indonesia saat ini, dimana jumlah BUMD yang "sakit" lebih banyak jika dibandingkan dengan statusnya yang "sehat". ${ }^{6}$

Dengan kondisi BUMD yang demikian, tujuan pendirian BUMD diragukan dapat tercapai dengan baik. Berdasarkan Pasal 331 ayat (4) UU No. 23 Tahun 2014 tentang Pemerintahan Daerah dan Pasal 7 Peraturan Pemerintah No. 54 Tahun 2017 tentang Badan Usaha Milik Daerah (PP No. 54 Tahun 2017), tujuan pendirian BUMD tersebut adalah untuk: a) memberikan manfaat bagi perkembangan perekonomian daerah; b) menyelenggarakan kemanfaatan umum berupa penyediaan barang dan/atau jasa yang bermutu bagi pemenuhan hajat hidup masyarakat sesuai kondisi, karakteristik dan potensi daerah yang bersangkutan berdasarkan tata kelola perusahaan yang baik; dan c) memperoleh laba dan/atau keuntungan. Laba dan/atau keuntungan BUMD menjadi sumber pendapatan daerah yang sangat bermanfaat untuk membiayai pembangunan guna meningkatkan kesejahteraan rakyat.

Rendahnya kualitas BUMD juga mengakibatkan BUMD belum siap menghadapi persaingan yang cukup ketat pada tataran nasional, regional, maupun internasional. Sementara saat ini globalisasi perekonomian telah terjadi, apalagi Indonesia telah menyepakati berbagai perjanjian internasional yang berimplikasi pada terjadinya liberalisasi perdagangan barang/jasa dan liberalisasi investasi. Beberapa perjanjian dimaksud adalah World Trade Organization (WTO), ASEAN Free Trade Area (AFTA), ASEAN Framework Agreement on Service, dan kerja sama ekonomi regional Asia Pasifik (Asia Pacific Economic Cooperation/APEC). Indonesia juga telah

Rizma Riyandi dan Budi Raharjo, 11 April 2017, "Pengamat: Jumlah BUMD Sakit Lebih Banyak Dibanding yang Sehat", http://www.republika.co.id/berita/koran/ dialog-jumat/15/01/02/ekonomi/makro/17/04/10/ oo733f415-pengamat-jumlah-bumd-sakit-lebih-banyakdibanding-yang-sehat, diakses tanggal 20 April 2017 menjadi anggota Masyarakat Ekonomi ASEAN/MEA (ASEAN Economic Community) yang mulai berlaku efektif pada tanggal 1 Januari 2016. MEA mengintegrasikan perekonomian negara-negara ASEAN sehingga ASEAN menjadi pasar tunggal dan basis produksi dimana terdapat arus bebas lalu lintas barang, jasa, investasi, tenaga kerja, dan modal. ${ }^{7}$ Globalisasi perekonomian mengakibatkan terjadinya persaingan tingkat tinggi (hyper-competition), oleh karenanya menuntut semua pelaku usaha termasuk BUMD memiliki kesiapan dan daya saing yang tinggi untuk menghadapinya.

Rendahnya kualitas BUMD tidak terlepas dari belum dikelolanya BUMD dengan baik berdasarkan pada tata kelola perusahaan yang baik (good corporate governance/GCG). Hal ini sebagaimana dikemukakan oleh Ketua Komisi 2 Dewan Perwakilan Daerah Republik Indonesia (DPD RI), Parlindungan Purba yang menyatakan bahwa buruknya kondisi BUMD disebabkan BUMD belum dikelola dengan baik. Pemerintah daerah selaku pemegang saham terbesar, bahkan menjadi pemegang saham pengendali banyak melakukan intervensi dalam pengelolaan BUMD. ${ }^{8}$ Intervensi tersebut dimungkinkan terjadi karena pemerintah daerah memiliki kewenangan yang yang cukup besar terhadap BUMD. Selain intervensi pemerintah daerah, bentuk hukum BUMD juga berimplikasi pada baik atau buruknya pengelolaan BUMD.

Berdasarkan pada paparan tersebut maka tulisan ini akan menganalisa mengenai implikasi bentuk hukum BUMD terhadap pengelolaan BUMD. Mengingat ada dua bentuk hukum BUMD yaitu perusahaan umum daerah (Perumda) dan Perusahaan Perseroan Daerah (Perseroda), maka tulisan ini akan menganalisa

\footnotetext{
Dian Cahyaningrum, "Perlindungan Konsumen dalam Transaksi Elektronik (E-Commerce) dalam Kerangka Masyarakat Ekonomi ASEAN" dalam Pembangunan Hukum dan Kebijakan Publik dalam Rangka Menyongsong Masyarakat Ekonomi ASEAN, Jakarta: P3DI Setjen DPR RI dan Azza Grafika, 2015, hal. 23.

Warta Ekonomi, 8 Februari 2016, "DPD: Banyak Masalah di BUMN dan BUMD”, https://www.wartaekonomi.co.id/ read89666/dpd-banyak-masalah-di-bumn-dan-bumd. html, diakses tanggal 21 April 2017.
} 
implikasi kedua bentuk hukum BUMD tersebut terhadap pengelolaannya. Adapun tujuan dari kajian ini adalah untuk mengetahui implikasi dari kedua bentuk hukum BUMD yaitu Perumda dan Perseroda terhadap pengelolaan Perumda dan Perseroda yang bersangkutan. Dilihat dari kegunaannya, kajian ini memiliki kegunaan teoritis dan praktis. Secara teoritis, kajian ini berguna untuk menambah ilmu pengetahuan hukum ekonomi, khususnya yang berkaitan dengan BUMD. Secara praktis, kajian ini diharapkan bermanfaat sebagai masukan bagi para pihak yang sedang membuat karya tulis ilmah tentang BUMD atau pun para pihak pembuat kebijakan yang berkaitan dengan BUMD.

Terkait dengan BUMD, banyak kajian atau penelitian terkait yang menjadikan BUMD sebagai obyek penelitian/kajian, diantaranya:

1. penelitian yang dilakukan oleh Yudho Taruno Muryanto dan Djuwityastuti yang berjudul "Model Pengelolaan Badan Usaha Milik Daerah (BUMD) dalam Rangka Mewujudkan Good Corporate Governance (GCG)".Penelitian inimerupakan penelitian empiris dengan menggunakan pendekatan perundang-undangan (Statute Approach), pendekatan konseptual (Analytical and Conceptual Approach) dengan menggunakan data primer dan sekunder. Penelitian dilakukan untuk mencari model pengelolaan BUMD. Hasil penelitian memaparkan ada dua model yang dapat digunakan untuk mengelola BUMD untuk mewujudkan GCG yaitu: Pertama, konsep pengelolaan BUMD non Persero 9 dengan menggunakan swakelola mandiri. Kewenangan Pemda selaku pemegang otoritas dapat melakukan intervensi kebijakan dengan menerbitkan peraturan kepala daerah baik peraturan gubernur/walikota/bupati yang secara substansi mengatur tentang rencana strategis BUMD tersebut. Kedua, konsep pengelolaan BUMD Persero dengan menggunakan model holding company dengan tipe prosedur

Penelitian ini menggunakan istilah non Persero bagi BUMD yang tidak berbentuk Persero. terprogram dengan group usaha kombinasi. Dipilihnya model holding company dengan tipe prosedur terprogram karena tipe atau karakter jenis usaha yang ada di pemerintah daerah beragam. ${ }^{10}$

2. Penelitian hukum yang dilakukan oleh Ronny Sautma Hotma Bako yang berjudul "Permasalahan Hukum atas Bentuk Badan Hukum Pada Badan Usaha Milik Daerah". Penelitian ini dilakukan di Provinsi Sumatera Barat, Provinsi Nusa Tenggara Barat, dan Provinsi Kalimantan Selatan pada tahun 2009. Penelitian ini meneliti mengenai perbedaan konsepsi bentuk badan hukum BUMD yaitu apakah BUMD yang dibentuk seharusnya berbentuk perseroan terbatas (PT) ataukah perusahaan daerah (Perusda) karena tidak ada kejelasan mengenai pemilihan bentuk hukum tersebut pada saat mendirikan BUMD. Pemilihan bentuk penting karena terkait dengan konsekuensinya, yaitu PT mencari keuntungan sedangkan Perusda untuk pelayanan publik. Penelitian ini hanya fokus pada BUMD di bidang perbankan dan pelayanan air minum. Di bidang perbankan, ketiga provinsi memiliki bank daerah. Namun bentuk hukum bank daerah di masing-masing provinsi tersebut berbeda-beda, ada yang berbentuk PT dan ada juga yang berbentuk Perusda. Ketiga provinsi juga memiliki BUMD sektor pelayanan air minum dan semuanya berbentuk Perusda. ${ }^{11}$

3. Penelitian mengenai "Kajian yuridis Bentuk Hukum Badan Usaha Milik Daerah (BUMD) di Bidang Perbankan Pasca Berlakunya Undang-Undang Nomor 23

\footnotetext{
10 Yudho Taruno Muryanto dan Djuwityastuti, "Model Pengelolaan Badan Usaha Milik Daerah (BUMD) dalam Rangka Mewujudkan Good Corporate Governance", Yustisia, Vol. 3, No. 1, Januari-April 2014, hal. 125-134, https://jurnal.uns.ac.id/yustisia/article/view/10136/9044, diakses tanggal 2 Mei 2017

11 Ronny Sautma Hotma Bako, "Permasalahan Hukum Atas Bentuk Badan Hukum pada Badan Usaha Milik Daerah”, Kajian, Vol.15 No.4, 2010, hal. 751-775, https://jurnal. dpr.go.id/index.php/kajian/article/view/589., diakses tanggal 29 Januari 2018
} 
Tahun 2014 tentang Pemerintah Daerah", yang dilakukan oleh Dhimas Tetuko Kusumo, Munawar Kholis, dan Sentot Sudarwanto. Penelitian ini merupakan penelitian doktrinal atau normatif yang meneliti mengenai bentuk hukum BUMD di bidang perbankan pasca dibentuknya UU No. 23 Tahun 2014 tentang Pemerintahan Daerah (UU No. 23 Tahun 2014). Konsekuensi yuridis dari berlakunya UU No. 23 Tahun 2014 terhadap bentuk hukum BUMD di bidang perbankan pada masa transisi yaitu maksimal 3 tahun setelah 2 Oktober 2014, sejak diundangkannya dan mulai berlakunya UU No. 23 Tahun 2014, terhadap BUMD bidang perbankan yang masih berbentuk Perusda tetap diakui dan diberikan waktu untuk mengubah bentuk hukumnya sesuai Pasal 331 ayat (3) UU No. 23 Tahun 2014. Bentuk hukum yang cocok untuk BUMD di bidang perbankan adalah Perseroda, dan bukan Perumda karena bidang perbankan bukan merupakan bidang vital atau mempengaruhi hajat orang banyak. ${ }^{12}$

Pada dasarnya kajiaan mengenai implikasi bentuk hukum BUMD terhadap pengelolaannya, berbeda dengan penelitianpenelitian tersebut karena dilakukan setelah dibentuknya PP No. 54 Tahun 2017 tentang Badan Usaha Milik Daerah yang merupakan aturan pelaksanaan dari pengaturan BUMD yang terdapat dalam UU No. 23 Tahun 2014. Selain itu permasalahan yang dikaji juga berbeda. Permasalahan yang diteliti dalam penelitian-penelitian tersebut adalah mengenai model pengelolaan BUMD, pemilihan bentuk hukum BUMD, dan bentuk hukum BUMD di bidang perbankan pasca UUNo. 23 Tahun 2014. Sedangkan kajian ini mengkaji permasalahan

12 Dhimas Tetuko Kusumo, Munawar Kholis, dan AL. Sentot Sudarwanto, "Kajian yuridis Bentuk Hukum Badan Usaha Milik Daerah (BUMD) di Bidang Perbankan Pasca Berlakunya Undang-Undang Nomor 23 Tahun 2014 tentang Pemerintah Daerah", Privat Law, Vol. IV, No. 1, Januari-Juni 2016, hal. 21-29, https://media.neliti.com/ media/publications/164480-ID-kajian-yuridis-bentukhukum-badan-usaha.pdf, diakses tanggal 3 Juni 2018 implikasi dari bentuk hukum BUMD terhadap pengelolaannya. Dengan demikian kajian ini merupakan kajian baru yang berbeda dengan kajian atau penelitian sebelumnya.

\section{BENTUK HUKUM BUMD}

Otonomi daerah diberikan kepada pemerintah daerah agar dapat mengatur dan mengurus sendiri urusan pemerintahan menurut asas otonomi dan tugas pembantuan. Bahkan otonomi daerah diberikan seluasluasnya untuk mempercepat terwujudnya kesejahteraan masyarakat, selain juga untuk meningkatkan daya saing daerah dalam sistem Negara Kesatuan Republik Indonesia. Untuk itu pemerintah daerah dapat mengatur sendiri beberapa bidang kehidupan di daerahnya, diantaranya bidang sosial, budaya, kesehatan, pendidikan, ekonomi, dan sebagainya.

Di bidang ekonomi, pemerintah daerah dapat mendirikan BUMD untuk mengelola potensi daerah, meningkatkan perekonomian daerah, dan memberikan pelayanan kepada masyarakat untuk mewujudkan kesejahteraan dan kemakmuran masyarakat. Adapun yang dimaksud dengan BUMD berdasarkan Pasal 1 angka 40 UU No. 23 Tahun 2014 dan Pasal 1 angka 1 PP No. 54 Tahun 2017 adalah badan usaha yang seluruh atau sebagian besar modalnya dimiliki oleh daerah. Berdasarkan pada pengertian tersebut, sebagaimana disebutkan dalam Pasal 6 PP No. 54 Tahun 2017, BUMD memiliki karakteristik sebagai berikut:

a. Badan usaha didirikan oleh pemerintah daerah;

b. Badan usaha dimiliki oleh: 1) 1 (satu) pemerintah daerah; 2) lebih dari 1 (satu) pemerintah daerah; 3) 1 (satu) pemerintah daerah dengan bukan daerah; atau 4) lebih dari 1 (satu) pemerintah daerah dengan bukan daerah.

c. Seluruh atau sebagian besar modalnya merupakan kekayaan daerah yang dipisahkan.

d. Bukan merupakan organisasi perangkat daerah; dan

e. Dikelola dengan menggunakan kelaziman dalam dunia usaha. 
Pendirian BUMD ditetapkan dengan peraturan daerah (Perda) dan didasarkan pada kebutuhan daerah dan kelayakan bidang usaha BUMD yang akan dibentuk. Kebutuhan daerah dikaji melalui studi yang mencakup aspek pelayanan umum dan kebutuhan masyarakat. Sedangkan kelayakan bidang usaha BUMD dikaji melalui analisis terhadap kelayakan ekonomi, analisis pasar dan pemasaran, analisis kelayakan keuangan, dan analisis aspek lainnya. Analisis aspek lainnya berisi aspek peraturan perundang-undangan, ketersediaan teknologi, dan ketersediaan sumber daya manusia. ${ }^{13}$

Berdasarkan pada pengertian BUMD sebagaimana telah dipaparkan, maka ada dua bentuk hukum BUMD yaitu: Perumda dan Perseroda. Berdasarkan pada Pasal 334 ayat (1) UU No. 23 Tahun 2014 dan Pasal 5 ayat (1) PP No. 54 Tahun 2017, Perumda adalah BUMD yang seluruh modalnya dimiliki oleh satu daerah dan tidak terbagi atas saham. Dengan demikian, mengacu pada karakteristik BUMD yang terdapat dalam Pasal 6 PP No. 54 Tahun 2017, Perumda hanya dapat dimiliki oleh satu daerah. Sedangkan yang dimaksud dengan Perseroda berdasarkan Pasal 339 ayat (1) UU No. 23 Tahun 2014 dan Pasal 5 ayat (2) PP No. 54 Tahun 2017 adalah BUMD yang berbentuk Perseroan Terbatas (PT) yang modalnya terbagi dalam saham yang seluruhnya atau paling sedikit 51\% (lima puluh satu persen) sahamnya dimiliki oleh satu daerah.

Mengingat bentuk Perseroda adalah PT, maka Perseroda juga harus tunduk pada UU No. 40 Tahun 2007 tentang Perseroan Terbatas (UU No. 40 Tahun 2007). Perseroan terbatas adalah persekutuan yang berbentuk badan hukum, yang disebut "perseroan". ${ }^{14}$ Pengertian Perseroan Terbatas (PT) juga terdapat dalam Pasal 1 angka 1 UU No. 40 Tahun 2007 yang menyebutkan PT adalah badan hukum yang merupakan persekutuan modal, didirikan berdasarkan perjanjian, melakukan kegiatan usaha dengan modal dasar yang seluruhnya

$13 \quad$ Pasal 331 ayat (5) UU No. 23 Tahun 2014 beserta penjelasannya dan Pasal 9 PP No. 54 Tahun 2017.

14 C.S.T. Kansil dan Christine S.T.Kansil, Seluk Beluk Perseroan Terbatas Menurut Undang-Undang No. 40 Tahun 2007, Jakarta: Rineka Cipta, 2009, hal. 2. terbagi dalam saham dan memenuhi persyaratan yang ditetapkan dalam UU No. 40 Tahun 2007 beserta aturan pelaksanaannya. Istilah perseroan pada PT menunjuk pada cara penentuan modal pada badan hukum itu yang terdiri dari sero-sero atau saham-saham dan istilah terbatas menunjuk pada batas tanggung jawab para pesero atau pemegang saham yaitu hanya terbatas pada jumlah nilai nominal dari semua saham-saham yang dimiliki. ${ }^{15}$

Tanggung jawab terbatas pemegang saham pada nilai nominal saham yang dimiliki tersebut merupakan penjabaran dari prinsip pertanggungjawaban terbatas dari pemegang saham. Pertanggungjawaban terbatas atau limited liability atau limitatief aansprakelijheid atau tanggung jawab terbatas adalah suatu kondisi dimana pemegang saham atau shareholder atau aandelhouder dari suatu perseroan hanya bertanggung jawab sebatas pada sejumlah saham yang mereka miliki di perseroan. ${ }^{16}$ Dalam PP No. 54 Tahun 2017, prinsip tersebut diatur dalam Pasal 20 yang menyebutkan modal BUMD yang bersumber dari penyertaan modal daerah merupakan batas pertanggungjawaban daerah atas kerugian BUMD.

Berpijak pada pengertian Perseroda sebagaimana telah dipaparkan, terlihat bahwa daerah dapat memiliki seluruh atau 100\% (seratus persen) saham Perseroda. Kepemilikan saham 100\% (seratus persen) oleh daerah tidak melanggar UU No. 40 Tahun 2007 yang mewajibkan pendirian PT harus dilakukan oleh 2 orang atau lebih. Ini disebabkan ada pengecualian sebagaimana diatur dalam Pasal 7 ayat (7) UU No. 40 Tahun 2007 yang menyebutkan ketentuan yang mewajibkan PT didirikan oleh 2 orang atau lebih tidak berlaku bagi Persero yang semua sahamnya dimiliki oleh negara. Dengan kepemilikan saham 100\% (seratus persen), maka secara otomatis yang menjadi pemilik dari Perseroda hanyalah daerah yang bersangkutan.

Ibid.

H. Zainal Asikin dan Wira Pria Suhartana, Pengantar Hukum Perusahaan, cetakan ke-1, Jakarta: Prenadamedia Group, 2016, hal. 71. 
Dari pengertian Perseroda juga dimungkinkan bagi daerah untuk memiliki saham setidaknya 51\% (lima puluh satu persen). Ini berarti terbuka kemungkinan bagi pihak lain untuk memiliki saham Perseroda, asalkan paling sedikit 51\% (lima puluh satu persen) saham Perseroda dimiliki oleh satu daerah. Dengan demikian, Perseroda dapat dimiliki oleh: ${ }^{17}$

1. Satu pemerintah daerah yang memiliki seluruh saham Perseroda.

2. Lebih dari satu pemerintah daerah, dimana salah satu pemerintah daerah memiliki paling sedikit $51 \%$ saham.

3. Satu pemerintah daerah dengan bukan daerah, dimana pemerintah daerah yang bersangkutan memiliki saham paling sedikit $51 \%$.

4. Lebih dari satu pemerintah daerah dengan bukan daerah, dimana salah satu pemerintah daerah memiliki saham paling sedikit $51 \%$.

Mengingat satu daerah harus memiliki saham paling sedikit 51\%, maka dalam hal Perseroda dimiliki oleh lebih dari satu pemerintah daerah, salah satu pemerintah daerah harus memiliki saham Perseroda lebih dari 51\%.

Baik Perumda maupun Perseroda adalah badan usaha yang berbentuk badan hukum. Berdasarkan Pasal 4 ayat (4) PP No. 54 Tahun 2017, status badan hukum Perumda diperoleh pada saat perda yang mengatur mengenai pendirian Perumda mulai berlaku. Sedangkan untuk Perseroda, berdasarkan Pasal 4 ayat (5) PP No. 54 Tahun 2017, kedudukan Perseroda sebagai badan hukum diperoleh sesuai dengan ketentuan undang-undang yang mengatur mengenai PT, yaitu UU No. 40 Tahun 2007. Berdasarkan Pasal 7 ayat (4) UU No. 40 Tahun 2007, Perseroda memperoleh status badan hukum pada tanggal diterbitkannya Keputusan Menteri ${ }^{18}$ mengenai pengesahan badan hukum Perseroan.

Adapun yang dimaksud dengan badan hukum (rechtspersoon) menurut burgerlijk wetboek (BW) atau KUH Perdata, adalah

Pasal 6 ayat (1) huruf b PP No. 54 Tahun 2017.

Menteri yang tugas dan tanggung jawabnya di bidang hukum dan hak asasi manusia. sekumpulan orang yang di dalam lalu lintas hukum bertindak seakan-akan ia adalah satu badan pribadi tunggal atau corporatie. Sedangkan menurut Van Apeldoorn, badan hukum adalah tiap-tiap kekayaan dengan tujuan tertentu, tetapi tanpa eigenaar atau owner atau pemilik, yang di dalam lalu lintas hukum diperlakukan sebagai badan pribadi. ${ }^{19}$

Sebagai suatu badan hukum, Perumda dan Perseroda diperlakukan sebagai manusia yang memiliki hak dan kewajiban, memiliki kekayaan sendiri, serta dapat melakukan tindakan hukum. Hal ini sesuai dengan teori fiksi (fictie theorie) dari Von Savigny bahwa badan hukum dianggap sebagai hal yang abstrak, tidak nyata karena tidak memiliki kekuasaan untuk menyatakan kehendak, hanya manusia yang memiliki kehendak. Badan hukum dianggap seolah-olah manusia. Oleh karena itu, tindakan badan hukum dianggap sebagai tindakan manusia. Jika manusia dalam tindakannya memiliki tanggung jawab maka badan hukum juga bertanggung jawab atas tindakan yang dilakukannya. ${ }^{20}$ Mengingat badan hukum dianggap sebagai hal yang abstrak karena tidak memiliki kekuasaan untuk menyatakan kehendak, maka organ badan hukum memiliki peran yang sangat penting karena organ itulah yang melakukan pengurusan dan mewakili badan hukum dalam melakukan suatu tindakan.

\section{IMPLIKASI BENTUK HUKUM BUMD A. IMPLIKASI BENTUK HUKUM PERUMDA}

Sebagaimana telah dipaparkan Perumda hanya dapat dimiliki oleh satu daerah. Pada Perumda, kepala daerah mewakili pemerintah daerah dalam kepemilikan kekayaan daerah yang dipisahkan (KPM), berkedudukan sebagai pemilik modal. Berdasarkan Pasal 1 angka 4 PP No. 54 Tahun 2017, KPM merupakan organ Perumda yang memiliki kekuasaan tertinggi dalam Perumda dan memegang segala

\footnotetext{
19 H. Zainal Asikin dan L. Wira Pria Suhartana, Pengantar Hukum Perusahaan, hal. 57-58.

20 Abdulkadir Muhammad, Hukum Perusahaan Indonesia, Bandung: Citra Aditya Bakti, 2010, hal. 103
} 
kewenangan yang tidak diserahkan kepada direksi atau dewan pengawas.

Kepemilikan seluruh modal oleh satu daerah tersebut penting karena sebagaimana disebutkan dalam Pasal 8 PP No. 54 Tahun 2017, pendirian Perumda diprioritaskan untuk menyelenggarakan kemanfaatan umum berupa penyediaan barang dan/atau jasa yang bermutu bagi pemenuhan hajat hidup masyarakat sesuai kondisi, karakteristik dan potensi daerah yang bersangkutan berdasarkan tata kelola perusahaan yang baik. Dalam Penjelasan Pasal 8 PP No. 54 Tahun 2017 dijelaskan bahwa yang dimaksud dengan "penyediaan kemanfaatan umum" antara lain: a) usaha perintisan berupa penyediaan barang dan/atau jasa yang bermutu dan terjangkau oleh masyarakat; dan b) usaha penyediaan pelayanan air minum yang lebih efisien jika dibandingkan dengan penyediaan oleh perangkat daerah. Dengan memiliki seluruh modal maka daerah dapat menentukan arah kebijakan Perumda untuk menyelenggarakan kemanfaatan umum guna memenuhi hajat hidup masyarakat dengan baik.

Sebagai entitas bisnis yang menyelenggarakan kemanfaatan umum untuk meningkatkan kesejahteraan masyarakat, tarif jasa dan/atau barang yang diproduksi Perumda diupayakan semurah mungkin agar terjangkau oleh semua lapisan masyarakat. Bahkan tarif jasa dan/atau barang yang diproduksi Perumda seperti air minum terkadang tidak sesuai dengan biaya produksi. Di sisi lain, meskipun bukan suatu prioritas, Perumda masih tetap harus mengejar target pendapatan asli daerah (PAD) yang telah ditetapkan. Kondisi tersebut dirasa cukup memberatkan Perumda karena harus "berdiri di dua kaki" yaitu di satu sisi harus memberikan pelayanan yang optimal kepada masyarakat (public service), dan di sisi yang lain juga harus mengejar target PAD yang telah ditetapkan.

Beratnya mengejar tujuan Perumda tersebut misalnya dikemukakan oleh Direksi Perusahaan Daerah Air Bersih Tirta Utama Jawa Tengah (PDAB Tirta Utama Jawa Tengah). Tarif air bersih yang diproduksi oleh PDAB Tirta Utama Jawa Tengah cukup rendah dan tidak sebanding dengan biaya produksinya. Namun untuk kepentingan pelayanan masyarakat, $\mathrm{PDAB}$ Tirta Utama Jawa Tengah tidak diperkenankan oleh KPM untuk menaikkan tarif air bersih, padahal biaya produksi air bersih cukup tinggi dan hasil penjualan air bersih kurang signifikan untuk menutup biaya tersebut. Tarif air semakin dilarang untuk dinaikkan ketika mendekati pemilihan umum kepala daerah karena dikhawatirkan merusak citra kepala daerah yang mencalonkan diri kembali menjadi kepala daerah, selain juga dapat memberatkan masyarakat terutama yang berpenghasilan rendah. ${ }^{21}$

Pelayanan kepada masyarakat dan upaya untuk menghasilkan keuntungan semakin berat karena PDAB Tirta Utama Jawa Tengah juga kekurangan dana untuk melakukan reinvestment yang diperlukan untuk memperbaiki pipa saluran air yang sudah tua dan banyak yang bocor. Kurangnya dana reinvestment disebabkan antara lain keuntungan yang dihasilkan oleh PDAB Tirta Utama Jawa Tengah kecil sehingga kapitalisasi cadangan juga kecil, apalagi sebagian keuntungan tersebut juga harus diserahkan kepada daerah selaku pemilik modal. Tidak adanya reinvestment mengakibatkan biaya produksi air bersih semakin tinggi dan tidak akan tertutup jika tidak ada tambahan modal. ${ }^{22}$

Berdasarkan Pasal 332 UU No. 23 Tahun 2014 dan Pasal 19 ayat (1) PP No. 54 Tahun 2017, tambahan modal Perumda dapat diperoleh dari: a) penyertaan modal daerah; b) pinjaman; c) hibah; dan d) sumber modal lainnya, di antaranya dari kapitalisasi cadangan dan keuntungan revaluasi aset. Namun tambahan modal dari penyertaan modal daerah dan pinjaman tidak seketika dapat didapatkan karena harus mendapatkan persetujuan dari kepala daerah dan DPRD mengingat penyertaan modal tersebut harus ditetapkan dengan Perda. Penyertaan modal dapat berupa uang dan barang milik daerah. Barang milik daerah yang disertakan tersebut harus dinilai sesuai nilai riil

\footnotetext{
21 Hesty Lilianti (Direksi PDAB Tirta Utama Jawa Tengah), Wawancara dilakukan di Kantor PDAB Tirta Utama Jawa Tengah pada tanggal 28 September 2017. 22 Ibid.
} 
pada saat barang milik daerah tersebut akan dijadikan penyertaan modal. Nilai riil tersebut diperoleh dengan melakukan penafsiran harga barang milik daerah sesuai dengan ketentuan peraturan perundang-undangan yang berlaku. ${ }^{23}$

Seperti halnya PDAB Tirta Utama Jawa Tengah, Perusahaan Daerah Air Bersih Jawa Timur (PDAB Jawa Timur) juga mengemukakan beratnya "berdiri di dua kaki" untuk mencapai dua tujuan Perumda. Di satu sisi PDAB Jawa Timur dituntut untuk menghasilkan keuntungan, sedangkan di sisi yang lain juga harus memberikan pelayanan yang optimal kepada masyarakat dan industri di kawasan industri dengan menyediakan air bersih. Penyediaan air bersih di kawasan industri dimaksudkan untuk menarik penanaman modal asing masuk ke Jawa Timur yang bermanfaat untuk terciptanya lapangan kerja dan meningkatkan pertumbuhan ekonomi daerah. Dalam rangka memberikan pelayanan kepada masyarakat, tarif air bersih PDAB Jawa Timur cukup kecil agar tidak membebani masyarakat. Penetapan tarif air bersih dilakukan oleh Gubernur. Tarif air tidak akan dinaikkan jika ada penolakan dari masyarakat. Kecilnya tarif air yang kurang sepadan dengan biaya produksi mengakibatkan keuntungan yang dihasilkan juga sangat kecil. ${ }^{24}$

Pada perkembangannya, berdasarkan Pasal 114 ayat (2) PP No. 54 Tahun 2017, Perumda dapat berubah bentuk menjadi Perseroda. Bahkan Pasal 334 ayat (2) UU No. 23 Tahun 2014 mengamanatkan untuk melakukan perubahan bentuk Perumda menjadi Perseroda dalam hal Perumda akan dimiliki oleh lebih dari satu daerah. Terkait dengan perubahan bentuk hukum tersebut, UU No. 23 Tahun 2014 dan aturan pelaksananya yaitu PP

23 Made Gde Subha Karma Resen; Yudho Taruno Muryanto, "Implikasi Yuridis Diundangkannya UndangUndang Nomor 23 Tahun 2014 tentang Pemerintahan Daerah terhadap Pengaturan Badan Usaha Milik Daerah di Indonesia", Yustisia, Vol.3, No.3, Edisi 90 SeptemberDesember 2014, hal. 127-135, www.portalgaruda.org., diakses tanggal 5 Juni 2018.

24 Tri Utoyo (Kabid Keuangan dan Pembukuan PDAB Jawa Timur), wawancara dilakukan di PDAB Jawa Timur pada tanggal 10 Agustus 2017.
No. 54 Tahun 2017 tidak mengatur perubahan tujuannya. Pasal 114 ayat (2) PP No. 54 Tahun 2017 hanya memberikan petunjuk bahwa perubahan bentuk hukum BUMD tesebut dilakukan dalam rangka mencapai tujuan dan restrukturisasi, tanpa menyebutkan tujuan seperti apa yang akan dicapai setelah terjadi perubahan bentuk hukum tersebut. Akibatnya tidak ada kejelasan apakah tujuan Perseroda hasil perubahan bentuk hukum dari Perumda juga ikut berubah, yaitu tidak lagi berorientasi pada pelayanan umum melainkan lebih menitikberatkan pada keuntungan (business oriented). Ketidakjelasan tersebut muncul karena PT (Perseroda) bertujuan untuk mencari keuntungan. Hal ini sebagaimana dikemukakan oleh Prof. Soekardono bahwa PT adalah suatu perikatan yang bercorak khusus untuk tujuan memperoleh keuntungan ekonomis. ${ }^{25}$ Meskipun tidak ada pengaturan mengenai perubahan tujuan dimaksud, perubahan bentuk Perumda menjadi Perseroda diharapkan tidak merugikan masyarakat.

Selain harus "berdiri di dua kaki", implikasi lain dari bentuk hukum Perumda adalah besarnya kewenangan kepala daerah selaku KPM. Hal ini dapat dilihat dalam Pasal 3 ayat (1) PP No. 54 Tahun 2017 yang menyebutkan bahwa kepala daerah mewakili pemerintah daerah dalam kepemilikan kekayaan daerah yang dipisahkan pada Perumda berkedudukan sebagai pemilik modal. Dalam kedudukannya tersebut, kepala daerah mempunyai kewenangan untuk mengambil keputusan yang dapat dilimpahkan kepada pejabat perangkat daerah. ${ }^{26}$

Pelimpahan kewenangan tersebut antara lain: a) perubahan anggaran dasar; b) pengalihan aset tetap; c) kerjasama; d) investasi dan pembiayaan, termasuk pembentukan anak perusahaan dan/atau penyertaan modal; e) penyertaan modal pemerintah daerah untuk Perumda yang bersumber dari kapitalisasi cadangan dan keuntungan revaluasi aset; f) pengangkatan dan pemberhentian dewan pengawas dan direksi;

\footnotetext{
25 Richard Burton Simatupang, Aspek Hukum dalam Bisnis, Edisi Revisi, Jakarta: Rineka Cipta, 2007, hal. 3.

$26 \quad$ Pasal 3 ayat (2) dan ayat (3) PP No. 54 Tahun 2017.
} 
g) penghasilan dewan pengawas dan direksi; h) penetapan besaran penggunaan laba; i) pengesahan laporan tahunan; j) penggabungan, pemisahan, peleburan, pengambilalihan, dan pembubaran BUMD; dan k) jaminan aset berjumlah lebih dari 50\% (lima puluh persen) dari jumlah kekayaan bersih BUMD dalam 1 (satu) transaksi atau lebih. ${ }^{27}$ Besarnya kewenangan KPM tersebut mengakibatkan perkembangan Perumda bergantung pada visi-misi dan niat baik dari KPM. Apabila KPM memiliki visi-misi dan niat yang baik, besar kemungkinan Perumda juga akan berkembang dengan baik. Sebaliknya jika tidak ada dukungan atau pun KPM kurang memiliki visi-misi dan niat yang kurang baik maka sulit bagi Perumda untuk berkembang.

Mengacu kepada kewenangan tersebut terlihat bahwa salah satu kewenangan dari KPM adalah mengangkat dan memberhentikan direksi dan dewan pengawas. Bahkan KPM berwenang mengangkat direksi untuk periode yang kedua dan ketiga. Hal ini disebutkan dalam Pasal 59 ayat (2) PP No. 54 Tahun 2017 yaitu jika direksi dinilai mampu melaksanakan tugas dengan baik selama masa jabatannya maka dapat diangkat kembali tanpa melalui proses seleksi lagi. Selanjutnya berdasarkan Pasal 61 huruf b PP No. 54 Tahun 2017, direksi dapat diangkat kembali untuk masa jabatan yang ketiga jika memiliki keahlian khusus dan/atau prestasi khusus yang sangat baik. Terkait dengan hal ini, PP No. 54 Tahun 2017 tidak menjelaskan apa yang dimaksud dengan "keahlian khusus" atau "prestasi yang sangat baik" sehingga kurang ada kejelasan parameter atau panduan yang digunakan untuk mengangkat direksi untuk periode ketiga.

Sebagaimana disebutkan dalam Pasal 29 ayat (2) PP No. 54 Tahun 2017, direksi dan dewan pengawas adalah organ Perumda. Oleh karena itu, sesuai dengan teori organ (organt theorie) direksi dan dewan pengawas memiliki peran penting mewakili Perumda selaku badan hukum untuk melakukan suatu tindakan untuk kepentingan dan atas nama Perumda. Teori organ tersebut dikembangkan oleh Von Gierke yang mengemukakan bahwa badan

$27 \quad$ Pasal 3 ayat (4) PP No. 54 Tahun 2017. hukum bukanlah hal yang fiktif, melainkan sebagai kenyataan yang tidak berbeda dengan manusia. Jika manusia mempunyai alat (organ) seperti otak untuk berpikir, tangan untuk berbuat, ataupun mulut untuk berkata menyatakan kehendak, maka badan hukum juga mempunyai alat (organ) yang bertindak untuk kepentingan dan atas nama badan hukum. Dengan kata lain, badan hukum diwakili oleh organnya. ${ }^{28}$

Mengingat pentingnya direksi dan dewan pengawas sebagai organ Perumda yang mewakili Perumda maka direksi dan dewan pengawas harus dapat menjalankan tugasnya dengan baik, independen, tanpa ada intervensi dari siapa pun dan dalam bentuk apa pun. Adapun tugas direksi berdasarkan Pasal 55 ayat (1) PP No. 54 Tahun 2017 adalah melakukan pengurusan Perumda. Sedangkan tugas dewan pengawas sebagaimana diatur dalam Pasal 43 ayat (1) PP No. 54 Tahun 2017 adalah: a) melakukan pengawasan terhadap Perumda; dan b) mengawasi dan memberi nasehat kepada direksi dalam menjalankan pengurusan Perumda.

Independensi direksi dan dewan pengawas dalam melaksanakan tugasnya tersebut, tanpa ada intervensi dari siapapun termasuk dari KMP dan dalam bentuk apa pun merupakan pelaksanaan dari tata kelola perusahaan yang baik (good corporate governance/GCG). Forum for Corporate Governance in Indonesia (FCGI) mendefinisikan Good Corporate Governance sebagai perangkat peraturan yang mengatur hubungan antara pemegang saham, pengurus (pengelola) perusahaan, pihak kreditur, pemerintah, karyawan, serta para pemegang kepentingan intern dan ekstern lainnya yang berkaitan dengan hak-hak dan kewajiban mereka atau dengan kata lain suatu sistem yang mengatur dan mengendalikan perusahaan. ${ }^{29}$ Pengertian tata kelola perusahaan yang baik juga dapat ditemukan dalam Pasal 1 angka 9 PP No. 54 Tahun 2017 yang mendefinisikan

\footnotetext{
28 Abdulkadir Muhammad, Hukum Perusahaan Indonesia, hal. 103

29 Komite Nasional Kebijakan Governance, "Pengertian Good Corporate Governance”, http://muc-advisory.com/ tag/komite-nasional-kebijakan-governance-knkg/mucadvisory.com., diakses tanggal 17 April 2018.
} 
tata kelola perusahaan yang baik sebagai sistem pengelolaan yang mengarahkan dan mengendalikan perusahaan agar menghasilkan kemanfaatan ekonomi yang berkesinambungan dan keseimbangan hubungan antar pemangku kepentingan.

Sebagaimana disebutkan dalam Pasal 92 ayat (3) PP No. 54 Tahun 2017, penerapan tata kelola perusahaan yang baik tersebut bertujuan untuk:

a. Mencapai tujuan BUMD;

b. Mengoptimalkan nilai BUMD agar perusahaan memiliki daya saing yang kuat, baik secara nasional maupun internasional;

c. Mendorong pengelolaan BUMD secara profesional, efisien, dan efektif, serta memberdayakan fungsi dan meningkatkan kemandirian organ BUMD;

d. Mendorong agar organ BUMD dalam membuat keputusan dan menjalankan tindakan dilandasi nilai moral yang tinggi dan kepatuhan terhadap peraturan perundang-undangan, serta kesadaran tanggung jawab sosial BUMD terhadap pemangku kepentingan maupun kelestarian lingkungan di sekitar BUMD;

e. Meningkatkan kontribusi BUMD dalam perekonomian nasional; dan

f. Meningkatkan iklim usaha yang kondusif bagi perkembangan investasi nasional.

Terkait dengan tujuan GCG, I Ketut Mardjana mengungkapkan bahwa Corporate governance merupakan proses dan struktur pengelolaan bisnis dan urusan-urusan perusahaan lainnya dalam rangka meningkatkan kemakmuran korporasi dan akuntabilitas perusahaan dengan tujuan utama mewujudkan nilai pemegang saham yang optimal dalam jangka panjang dan dengan tetap memperhatikan kepentingan stakeholders yang lain. ${ }^{30}$

Agar tujuan tersebut tercapai maka pengelolaan perusahaan yang baik harus dilakukan berdasarkan pada prinsip: ${ }^{31}$

\footnotetext{
$30 \quad$ I Ketut Mardjana,"Corporate Governance dan Privatisasi," Jurnal Reformasi Ekonomi, Vol. 1, No. 2 (OktoberDesember 2002), hal.30-31.

$31 \quad$ Pasal 92 ayat (2) dan Penjelasan Pasal 92 ayat (2) PP No. 54 Tahun 2017.
}

1. Transparansi adalah keterbukaan dalam melaksanakan proses pengambilan keputusan dan keterbukaan dalam mengungkapkan informasi yang relevan mengenai perusahaan.

2. Akuntabilitas adalah kejelasan fungsi, pelaksanaan, dan pertanggungjawaban organ sehingga pengelolaan perusahaan terlaksana secara efektif.

3. Pertanggungjawaban adalah kesesuaian dalam pengelolaan perusahaan terhadap peraturan perundang-undangan dan prinsip korporasi yang sehat.

4. Kemandirian adalah keadaan dimana perusahaan dikelola secara profesional tanpa benturan kepentingan dan pengaruh/tekanan dari pihak manapun yang tidak sesuai dengan ketentuan peraturan perundang-undangan dan prinsip korporasi yang sehat.

5. Kewajaran adalah keadilan dan kesetaraan di dalam memenuhi hak pemangku kepentingan (stakeholders) yang timbul berdasarkan perjanjian dan peraturan perundang-undangan.

Mengacu pada pengertian Good Corporate Governance sebagaimana dipaparkan dan prinsip tata kelola perusahaan yang baik yaitu kemandirian maka masing-masing organ Perumda harus dapat melaksanakan tugasnya dengan baik dalam pengelolaan Perumda. Direksi dan anggota dewan pengawas harus dapat menjalankan tugasnya dengan baik, tanpa ada tekanan, paksaan atau pun pengaruh dari siapa pun termasuk KPM yang tidak sesuai dengan ketentuan peraturan perundangundangan. Pengaruh atau tekanan dari KPM tersebut dimungkinkan terjadi, apalagi direksi dan anggota dewan pengawas diangkat dan diberhentikan oleh KPM. Selain itu berdasarkan Pasal 3 ayat (4) PP No. 54 Tahun 2017, penghasilan direksi dan dewan pengawas juga diputuskan oleh KPM. Dengan kemandirian, diharapkan tujuan tata kelola perusahan yang baik yaitu Perumda dapat dikelola secara profesional, efektif, dan efisien dapat tercapai. 
Besarnya kewenangan KPM berimplikasi pada pelaksanaan tugas direksi dalam mengurus Perumda. Direksi kurang leluasa dan kurang berani dalam melakukan aksi bisnis (business action) dan ekspansi bisnis karena terlebih dahulu harus berkonsultasi dan meminta persetujuan dari KPM jika hendak mengambil keputusan atau tindakan strategis. Direksi hanya tinggal mengikuti arahan atau instruksi dari KPM. Sistem birokrasi yang demikian menyebabkan kinerja Perumda menjadi lamban.

Implikasi lain dari bentuk hukum Perumda adalah terkait dengan pegawai Perumda. Pasal 74 PP No. 54 Tahun 2017 mengatur bahwa pegawai BUMD merupakan pekerja BUMD yang pengangkatan, pemberhentian, kedudukan, hak, dan kewajibannya ditetapkan berdasarkan perjanjian kerja sesuai dengan ketentuan peraturan perundang-undangan yang mengatur mengenai ketenagakerjaan. Pada Perumda, tidak tertutup kemungkinan terjadi KKN dalam rekrutmen dan pengangkatan pegawainya, apalagi jika calon pegawai tersebut ada hubungan keluarga dengan pejabat daerah setempat. Selain itu, rekrutmen pegawai BUMD terkadang juga tidak diumumkan sehingga yang mengetahui informasi peluang kerja di Perumda tersebut hanyalah pegawainya. Oleh karena itu peluang kerja tersebut pada akhirnya diisi oleh anak atau saudara dari pegawai Perumda dimaksud. Mekanisme rekrutmen yang demikian bertentangan dengan prinsip tata kelola perusahaan yang baik yaitu transparansi mengenai adanya peluang bagi masyarakat untuk dapat bekerja di Perumda yang bersangkutan.

Cara perekrutan pegawai Perumda yang demikian selain merugikan masyarakat juga merugikan Perumda itu sendiri. Masyarakat dirugikan karena peluang kerja di Perumda tertutup. Sedangkan Perumda juga dirugikan karena cara perekrutan yang demikian dapat menghasilkan pegawai Perumda dengan kualitas dan budaya kerja yang rendah. Akibatnya hanya sedikit pegawai Perumda yang berkinerja baik yang dapat mendukung Direksi untuk mengelola Perumda. Direksi juga mengalami kesulitan dalam melaksanakan rencana kerja perusahaan karena kurang bisa mengandalkan pegawainya untuk bekerja mendukung rencana kerjanya. Untuk itu rekrutmen pegawai Perumda harus dilakukan secara profesional. Selain itu juga perlu ada peningkatan kualitas pekerja Perumda sebagaimana dimanatkan dalam Pasal 77 PP No. 54 Tahun 2017 yang mengamanatkan BUMD untuk melaksanakan program peningkatan kapasitas sumber daya manusianya dalam rangka untuk meningkatkan kompetensi pegawainya. Sebagaimana hasil penelitian yang dilakukan oleh Asep Ahmad Saefuloh, perlu ada perubahan cara pandang terhadap SDM dalam perusahaan. SDM tidak dilihat sebagai pekerja semata melainkan sebagai human capital karena keberadaannya menjadi aset penting perusahaan yang harus dipelihara dan dikembangkan demi kemajuan perusahaan. ${ }^{32}$

\section{IMPLIKASI BENTUK HUKUM PERSERODA}

Tidak seperti Perumda yang memberikan pelayanan kepada masyarakat (public service), Perseroda dibentuk dengan tujuan untuk mengelola potensi daerah guna mendorong perekonomian daerah dan menghasilkan keuntungan (profit oriented). Keuntungan Perseroda menjadi sumber Pendapatan Asli Daerah (PAD) yang diperlukan untuk pembangunan. Namun sebagaimana diatur dalam Pasal 114 ayat (3) huruf b PP No. 54 Tahun 2017, Perseroda dapat diubah bentuknya menjadi Perumda. Terkait dengan perubahan bentuk hukum tersebut, PP No. 54 Tahun 2017 tidak mengatur apakah tujuan Perumda hasil perubahan bentuk hukum dari Perseroda juga ikut berubah, yaitu yang semula profit oriented berubah menjadi berorientasi ke pelayanan masyarakat. Pertanyaan ini muncul karena UU No. 23 Tahun 2014 dan aturan pelaksananya yaitu PP No. 54 Tahun 2017 tidak memberikan

\footnotetext{
32 Asep Ahmad Saefuloh, "Kebijakan Pengelolaan Sumber Daya Manusia pada Badan Usaha Milik Daerah: Studi Kasus di Provinsi Sumatera Barat, Nusa Tenggara Barat dan Kalimantan Selatan”, Kajian, Vol. 15, No. 10, Maret 2010, hal. 59-84.
} 
petunjuk Perseroda yang seperti apa yang dapat berubah bentuk menjadi Perumda. Petunjuk yang diberikan hanyalah perubahan tersebut dapat dilakukan dalam rangka mencapai tujuan dan restrukturisasi, tanpa ada penjelasan tujuan seperti apa yang hendak dicapai sehingga perlu dilakukan perubahan bentuk dari Perseroda menjadi Perumda.

Mengingat tujuan utama Perseroda adalah profit oriented, maka direksi Perseroda dituntut untuk dapat melakukan terobosan atau pun aksi bisnis (business action) yang dapat menguntungkan Perseroda. Namun tidak tertutup kemungkinan aksi bisnis yang dilakukan oleh direksi justru menimbulkan kerugian pada Perseroda. Terkait dengan kerugian tersebut, direksi tidak perlu khawatir dipersalahkan selama direksi melakukan aksi bisnis dan kepengurusannya dengan itikad baik dan penuh tanggung jawab, sesuai dengan maksud dan tujuan didirikannya Perseroda sebagaimana tercantum dalam anggaran dasarnya. Hal tersebut merupakan pelaksanaan dari tugas fiduciary duties dari direksi, yaitu tugas yang terbit secara hukum (by the operation of law) dari suatu hubungan fiduciary antara direksi dan perusahaan (Perseroda) yang dipimpinnya sehingga direksi harus mempunyai kepedulian dan kemampuan (duty of care and skill), itikad baik, loyalitas, dan kejujuran terhadap perusahaan dengan derajat yang tinggi (high degree). ${ }^{33}$ Dalam melaksanakan tugas fiduciary duties, direksi harus melaksanakan tugasnya dengan itikad baik (Bona Fides), proper purpose, tidak dengan kebebasan yang tidak bertanggung jawab (Unfettered Discretion), dan tidak memiliki benturan tugas dan kepentingan (Conflict of Duty and Interest). ${ }^{34}$ Dalam UU No. 40 Tahun 2007, tugas fiduciary duty dapat dilihat dalam:

1. Pasal 92 ayat (1): Direksi menjalankan pengurusan perseroan untuk kepentingan perseroan dan sesuai dengan maksud dan tujuan perseroan.

\footnotetext{
33 Munir Fuady, Perseroan Terbatas Paradigma Baru, Bandung: Citra Aditya Bakti, 2003, hal. 81.

$34 \quad$ Ibid., hal. 82.
}

2. Pasal 92 ayat (2): Direksi berwenang menjalankan pengurusan sesuai dengan kebijakan yang dipandang tepat, dalam batas yang ditentukan dalam UU No. 40 Tahun 2007 dan/atau anggaran dasar.

3. Pasal 97 ayat (1): Direksi bertanggung jawab atas pengurusan perseroan.

4. Pasal 97 ayat (2): Pengurusan perseroan wajib dilaksanakan setiap anggota direksi dengan itikad baik dan penuh tanggung jawab.

Sepanjang direksi tidak melakukan pelanggaran atas anggaran dasar perseroan, maka perseroan yang akan bertanggung jawab atas semua akibat dari tindakan direksi tersebut, termasuk apabila perseroan menderita kerugian, bahkan kepailitan, sepanjang kerugian atau kepailitan tersebut terjadi bukan karena kesalahan (kesengajaan atau kelalaian) direksi. ${ }^{35} \mathrm{Hal}$ tersebut ditegaskan dalam Pasal 97 ayat (5) UU No. 40 Tahun 2007 bahwa anggota direksi tidak dapat dipertanggungjawabkan atas kerugian perseroan apabila dapat membuktikan:

a. Kerugian tersebut bukan karena kesalahan atau kelalaiannya;

b. Telah melakukan pengurusan dengan itikad baik dan kehati-hatian untuk kepentingan dan sesuai dengan maksud dan tujuan Perseroan;

c. Tidak mempunyai benturan kepentingan baik langsung maupun tidak langsung atas tindakan pengurusan yang mengakibatkan kerugian; dan

d. Telah mengambil tindakan untuk mencegah timbul atau berlanjutnya kerugian tersebut.

Sebaliknya apabila direksi tidak memiliki itikad baik, salah, dan lalai dalam melaksanakan tugas kepengurusan Perseroda, serta melakukan tindakan yang berhubungan dengan tindakan ultra vires maka berdasarkan Pasal 97 ayat (3) UU No. 40 Tahun 2007, setiap anggota direksi

Hasbullah F. Sjawie, "Tanggung Jawab Direksi Perseroan Terbatas Atas Tindakan Ultra Vires", Jurnal Hukum Prioris, Vol. 6 No. 1 Tahun 2017, https://media.neliti. com/media/publications/82266-ID-tanggung-jawabdireksi-perseroan-terbata.pdf., diakses tanggal 18 Mei 2018, hal. 12-32. 
harus bertanggung jawab penuh secara pribadi atas kerugian Perseroda. Dalam hal direksi terdiri atas 2 (dua) anggota direksi atau lebih, maka berdasarkan Pasal 97 ayat (4) UU No. 40 Tahun 2007 tanggung jawab tersebut berlaku secara tanggung renteng bagi setiap anggota direksi.
Sebagai hasil dari pelaksanaan tugas fiduciary duties, banyak Perseroda yang menghasilkan keuntungan yang cukup signifikan bahkan melampaui target PAD yang telah ditetapkan, contohnya Perseroda di Jawa Timur yang dapat dilihat pada tabel 1 sebagai berikut.

Tabel 1. Kondisi Keuangan Perseroda Jatim Periode 31 Desember 2016

\begin{tabular}{lrrrrr}
\hline $\begin{array}{c}\text { NAMA } \\
\text { Perseroda }\end{array}$ & \multicolumn{1}{c}{$\begin{array}{c}\text { Laba/Rugi } \\
(\mathrm{Rp})\end{array}$} & $\begin{array}{c}\text { Realisasi PAD } \\
(\mathrm{Rp})\end{array}$ & $\begin{array}{c}\text { Saham } \\
(\%)\end{array}$ & ROE & $\begin{array}{c}\text { Realisasi PAD 2016 Dibandingkan } \\
\text { Target PAD 2016 (\%) }\end{array}$ \\
\hline PT. Bank Jatim & 1.028 .216 .000 .000 & 335.020 .511 .599 & 51,46 & 14,26 & 100,61 \\
\hline PT. BPR Jatim & 27.322 .600 .145 & 12.202 .939 .000 & 90,21 & 5,79 & 104,30 \\
\hline PT. PWU & 9.915 .516 .894 & 3.989 .000 .000 & 100 & 5,89 & 100,00 \\
\hline PT. JGU & 5.884 .297 .748 & 3.000 .000 .000 & 99,95 & 0,76 & 100,00 \\
\hline PT. PJU & 42.366 .918 .119 & 5.500 .000 .000 & 99,97 & 7,25 & 100,00 \\
\hline PT. Jamkrida & 4.544 .537 .413 & 650.000 .000 & 99,72 & 2,31 & 100,00 \\
\hline PT. JPU. & 303.522 .941 & & 92,59 & 0,76 & 0,00 \\
\hline
\end{tabular}

Sumber: Biro Administrasi Perekonomian Provinsi Jawa Timur, 2017.

Tindakan yang berhubungan dengan tindakan ultra vires tersebut ada dua yaitu: pertama, adalah tindakan yang menurut ketentuan perundang-undangan yang berlaku serta anggaran dasar perseroan adalah tindakan yang berada di luar maksud dan tujuan perseroan. Kedua, adalah tindakan dari direksi perseroan di luar kewenangan yang diberikan kepadanya berdasarkan ketentuan yang berlaku, termasuk anggaran dasar. ${ }^{36}$ Tanggung jawab direksi sebagaiana diatur dalam Pasal 97 ayat (3) dan ayat (4) UU No. 40 Tahun 2007 tersebut sesuai dengan prinsip "piercing the corporate veil" atau "lifting the veil" yang dapat diartikan sebagai "membuka cadar atau tabir perusahan”. Menurut Black's Law Dictionary, yang dimaksud dengan piercing the corporate veil adalah "The judicial act of imposing personal liability on ohtherwise immune corporate officers, directors, and shareholders for the corporations's wrongful acts". ${ }^{37}$

\footnotetext{
36 Gunawan Widjaja, Tanggung Jawab Direksi atas Kepailitan Perseroan, Jakarta: RajaGrafindo Persada, 2005, hal. 2122.

37 Bryan A. Garner, Black's Law Dictionary, Eight Edition, St. Paul: Thomson West, 2004, hal. 1184.
}

Dari Tabel 1, PAD Perseroda di Provinsi Jawa Timur umumnya memenuhi target, hanya PT JPU yang tidak memenuhi target PAD. Bahkan PAD Perseroda di bidang perbankan yaitu PT Bank Jatim dan PT BPR Jatim melampaui target PAD yang telah ditetapkan. Ini dapat dipahami karena aturan dan pengawasan Otoritas Jasa Keuangan (OJK) yang cukup ketat di bidang perbankan mendorong terciptanya pengelolaan yang baik pada Perseroda yang menjalankan kegiatan usaha di bidang perbankan. Hasilnya perusahaan menunjukkan performa yang cukup memuaskan.

Hal tersebut sesuai dengan apa yang dikemukakan oleh Stijn Claessens mengenai tata kelola perusahaan (corporate governance) bahwa dalam pengertian tentang corporate governance dapat dimasukkan dalam dua kategori yaitu: kategori pertama, lebih condong pada serangkaian pola perilaku perusahaan yang diukur melalui kinerja, pertumbuhan, struktur pembiayaan, perlakuan terhadap para pemegang saham, dan stakeholders. kategori kedua lebih melihat pada kerangka secara normatif, yaitu segala ketentuan hukum 
baik yang berasal dari sistem hukum, sistem peradilan, pasar keuangan, dan sebagainya yang mempengaruhi perilaku perusahaan. ${ }^{38} \mathrm{Mengacu}$ pada kategori kedua maka ketentuan peraturan perundang-undangan, seperti peraturan OJK dan juga pengawasan yang dilakukan oleh OJK telah mendorong pengelolaan yang baik pada Perseroda bidang perbankan.

Berbeda dengan Perumda dimana kepala daerah berkedudukan sebagai pemilik modal, berdasarkan Pasal 3 ayat (1) huruf b PP No. 54 Tahun 2017, kepala daerah pada Perseroda mewakili pemerintah daerah dalam kepemilikan kekayaan daerah yang dipisahkan, berkedudukan sebagai pemegang saham. Dengan kepemilikan saham paling sedikit 51\% dan bahkan 100\%, maka kepala daerah berkedudukan sebagai pemegang saham mayoritas pada Perseroda. Terkait dengan kepemilikan saham mayoritas tersebut, Rudyanti Dorotea Tobing mengemukakan bahwa siapa yang menguasai saham paling banyak dalam suatu PT, maka dialah yang menentukan kebijakan PT. ${ }^{39}$

Pendapat Rudyanti Dorotea Tobing tersebut dapat dipahami karena Pasal 84 ayat (1) UU No. 40 Tahun 2007 mengatur setiap saham yang dikeluarkan mempunyai satu hak suara, kecuali anggaran dasar menentukan lain. Setiap pemegang saham berhak mengeluarkan suaranya sebanyak saham yang dimilikinya di dalam Perseroda. Dengan demikian berdasarkan Pasal 84 ayat (1) UU No. 40 Tahun 2007, dengan kepemilikan saham minimal 51\% atau bahkan 100\%, maka kepala daerah mewakili daerah sebagai pemegang saham mayoritas dan dapat mengambil keputusan dalam RUPS. Berdasarkan Pasal 1 angka 15 PP No. 54 Tahun 2017, RUPS adalah organ Perseroda yang memegang kekuasaan tertinggi dalam Perseroda dan memegang segala wewenang yang tidak diserahkan kepada direksi atau komisaris.

38 Indra Surya dan Ivan Yustiavandana, Penerapan Good Corporate Governance Mengesampingkan Hak-Hak Istimewa Demi Kelangsungan Usaha, Jakarta: Prenada Media Group, 2006, hal. 26

39 Rudyanti Dorotea Tobing, Aspek-Aspek Hukum Bisnis Pengertian, Asas, Teori, dan Praktik, Surabaya: LeksBang Justitia, 2015, hal. 268.
Dengan demikian dalam kedudukannya sebagai pemegang saham mayoritas, kepala daerah memiliki kewenangan yang besar dalam Perseroda dan dapat menentukan kebijakan Perseroda.

Besarnya kewenangan kepala daerah sebagai pemegang saham mayoritas tersebut dipertegas dalam Pasal 3 ayat (3) dan ayat (4) PP No. 54 Tahun 2017 yang menyebutkan bahwa kepala daerah selaku pemegang saham pada Perseroda memiliki kewenangan mengambil keputusan yang menyangkut: ${ }^{40} 1$ ) perubahan anggaran dasar; 2) pengalihan aset tetap; 3) kerjasama; 4) investasi dan pembiayaan, termasuk pembentukan anak perusahaan dan/atau penyertaan modal; 5) penyertaan modal pemerintah daerah bersumber dari modal kapitalisasi cadangan, keuntungan revaluasi aset, dan agio saham; 6) pengangkatan dan pemberhentian direksi dan komisaris; 7) penghasilan direksi dan komisaris; 8) penetapan besaran penggunaan laba; 9) pengesahan laporan tahunan; 10) penggabungan, pemisahan, peleburan, pengambilalihan, dan pembubaran Perseroda; dan 11) jaminan aset berjumlah lebih dari 50\% (lima puluh persen) dari jumlah kekayaan bersih Perseroda dalam (satu) transaksi atau lebih.

Dari kewenangan tersebut terlihat bahwa kepala daerah yang mewakili daerah sebagai pemegang saham mayoritas pada Perseroda, memiliki kewenangan untuk mengangkat organ Perseroda yaitu direksi dan komisaris. Berdasarkan teori organ, direksi bertugas melakukan pengurusan Perseroda dan memiliki peran penting untuk mewakili Perseroda baik di dalam maupun di luar pengadilan sesuai dengan anggaran dasar. Sedangkan komisaris bertugas melakukan pengawasan dan memberikan nasihat kepada direksi dalam menjalankan kegiatan pengurusan Perseroda. Mengingat peran pentingnya sebagai organ Perseroda tersebut, maka direksi dan komisaris haruslah orang yang benar-benar profesional yang memenuhi kualifikasi sebagaimana

Pasal 3 ayat (4) PP No. 54 Tahun 2017. 
dipersyaratkan dalam PP No. 54 Tahun 2017. ${ }^{41}$ Oleh karena itu pemilihan dan pengangkatan direksi dan komisaris harus dilakukan sesuai dengan ketentuan peraturan perundangundangan $^{42}$ dan tidak melalui KKN.

Keputusan yang diambil oleh kepala daerah baik yang terkait dengan pengangkatan direksi dan anggota komisaris maupun hal lainnya sebagaimana diatur dalam Pasal 3 ayat (3) dan ayat (4) PP No. 54 Tahun 2017 di atas tidak boleh merugikan pemegang saham minoritas. Berdasarkan UU No. 40 Tahun 2007, pemegang saham minoritas adalah pemegang saham yang memiliki jumlah saham tidak lebih dari 10\% (sepuluh persen). ${ }^{43}$ Berdasarkan pada prinsip tata kelola perusahaan yang baik yaitu kewajaran, Perseroda harus memperhatikan kepentingan seluruh stakeholders berdasarkan asas kepatutan dan kewajaran, khususnya kepentingan pemegang saham minoritas. Mengingat kedudukannya yang lemah maka hukum memberikan pelindungan kepada pemegang saham minoritas. Menurut Rachmadi Usman, perlunya pelindungan hukum terhadap pemegang saham minoritas disebabkan sebelum berlakunya undang-undang PT terdapat suatu kondisi dimana: ${ }^{44}$

1. Berlakunya "prinsip mayoritas" menyebabkan pemegang saham minoritas berada pada posisi yang tidak berdaya dalam menegakkan kepentingan dan haknya. Kedudukan hukum pemegang saham minoritas lemah dan tidak mampu menghadapi direksi/komisaris yang

41 Syarat untuk menjadi anggota Komisaris diatur dalam Pasal 38 PP No. 54 Tahun 2017. Sedangkan syarat untuk menjadi Direksi diatur dalam Pasal 58 PP No. 54 Tahun 2017.

42 Mekanisme pemilihan dan pengangkatan anggota Komisaris diatur dalam Pasal 39 dan Pasal 40 PP No. 54 Tahun 2017. Sedangkan pemilihan dan pengangkatan Direksi diatur dalam Pasal 58 dan Pasal 59 PP No. 54 Tahun 2017.

43 Maya Sari, Abdul Rachmad Budiono, dan Hanif Nur Widhiyanti, "Perlindungan Hukum Bagi Pemegang Saham Minoritas Yang tidak dilibatkan dalam Proses Akuisisi", Yuridika, Vol. 32, No.3, September 2017, hal. 441-463, www.e-jounal.unair.ac.id/YDK/arcticle/view/4827/pdf_2., diakses tanggal 18 Mei 2018.

44 Rachmadi Usman, Dimensi Hukum Perusahaan Perseroan Terbatas, Bandung: PT. Alumni, 2004, hal. 120-121. merugikan dirinya dan perseroan. Ini disebabkan kedudukan pemegang saham mayoritas identik dengan direksi/komisaris selaku organ perseroan, baik identik secara fisik maupun kepentingan.

2. Prinsip "personan standing in judicio" atau "capacity standing in court or in judgment" yaitu hak untuk mewakili perseroan hanya boleh dilakukan oleh organ perseroan yaitu direksi. Pemegang saham minoritas tidak boleh melakukan tindakan derivatif.

Dalam UU No. 40 Tahun 2007, pelindungan terhadap pemegang saham minoritas tersebut terdapat dalam Pasal 61 dan Pasal 62. Berdasarkan pada Pasal 61 UU No. 40 Tahun 2007, pemegang saham yang merasa dirugikan karena tindakan Perseroda yang dianggap tidak adil dan tanpa alasan wajar sebagai akibat keputusan RUPS, direksi, dan/atau dewan komisaris dapat mengajukan gugatan terhadap Perseroda ke pengadilan negeri yang daerah hukumnya meliputi tempat kedudukan Perseroda. Sedangkan berdasarkan Pasal 62 UU No. 40 Tahun 2007, setiap pemegang saham berhak meminta kepada Perseroda agar sahamnya dibeli dengan harga yang wajar apabila yang bersangkutan tidak menyetujui tindakan Perseroda yang merugikan pemegang saham atau Perseroda berupa:

a. Perubahan anggaran dasar.

b. Pengalihan atau penjaminan kekayaan Perseroda yang mempunyai nilai lebih dari 50\% (lima puluh persen) kekayaan bersih perseroda.

c. Penggabungan, peleburan, pengambilalihan, atau pemisahan.

Meskipun hukum memberikan pelindungan terhadap pemegang saham minoritas, jarang terjadi pemegang saham minoritas Perseroda yang mengajukan gugatan terhadap Perseroda ke pengadilan negeri atau pun meminta sahamnya dibeli oleh Perseroda karena merasa dirugikan oleh tindakan Perseroda. Ada kemungkinan hal tersebut disebabkan Perseroda memang telah dikelola dengan baik dan tidak merugikan pemegang saham minoritas. Kemungkinan lainnya, tidak ada keberanian dari pemegang 
saham minoritas untuk mengajukan gugatan terhadap Perseroda ke pengadilan negeri atau pun meminta sahamnya dibeli. Ketidakberanian tersebut disebabkan pemegang saham minoritas pada Perseroda umumnya adalah pemerintah kabupaten/kota yang berada di provinsi yang bersangkutan atau koperasi pegawai negeri. Sebagai contoh, pemegang saham minoritas pada PT. Pusat Rekreasi Promosi dan Pembangunan Jawa Tengah (PT. PRPP Jawa Tengah) adalah kabupaten/kota yang ada di Jawa Tengah. Contoh lainnya, pemegang saham minoritas pada PT. Sarana Pembangunan Jawa Tengah (SPJT) dan PT Jamkrida Jawa Tengah adalah koperasi pegawai.

Besarnya kewenangan kepala daerah pada Perseroda menyebabkan visi, misi, dan itikad baik kepala daerah dapat mempengaruhi perkembangan Perseroda. Perseroda akan berkembang dengan baik jika Kepala Daerah memiliki visi, misi, dan itikad baik untuk mengembangkannya. Sebaliknya Perseroda sulit untuk berkembang dengan baik jika kurang ada dukungan dari Kepala Daerah. Pada kondisi yang demikian, Perseroda semakin sulit untuk berkembang jika pemegang saham minoritas yang diharapkan dapat menjalankan fungsi kontrolnya terhadap Perseroda kurang bisa menjalankan fungsinya tersebut dengan baik. Untuk itu, dalam rangka untuk meningkatkan pengawasan akan lebih baik jika saham Perseroda juga dimiliki oleh masyarakat di daerah yang bersangkutan. ${ }^{45}$ Dengan kepemilikan saham oleh masyarakat luas maka diharapkan ada banyak pihak yang mengawasi Perseroda sehingga Perseroda dapat dikelola dan berkembang dengan baik. Perseroda yang berkembang dengan baik akan meningkatkan value perusahaan dan menaikkan nilai saham Perseroda yang pada akhirnya akan dapat menguntungkan daerah itu sendiri.

45 Agus (Dosen Hukum Perusahaan Fakultas Hukum Universitas Airlangga Surabaya), wawancara dilakukan di Fakultas Hukum Universitas Airlangga pada tanggal 9 Agustus 2017.

\section{PENUTUP}

Bentuk hukum BUMD berimplikasi pada pengelolaannya. Pada BUMD yang berbentuk Perumda, pengelolaan BUMD dirasa berat karena PP No. 54 Tahun 2017 mengamanatkan untuk memprioritaskan menyelenggarakan kepentingan umum, selain juga harus menghasilkan keuntungan. Pada Perumda, KMP memiliki kewenangan cukup besar sehingga memiliki peran penting dalam pengelolaan Perumda karena segala keputusan yang bersifat strategis harus mendapatkan persetujuan dari KMP. Dengan demikian visi, misi, dan niat baik KMP berpengaruh pada perkembangan Perumda. Perumda akan berkembang dengan baik jika KMP memiliki visi, misi, dan niat yang baik untuk mengembangkannya, begitu pun sebaliknya. Selain KMP, direksi dan dewan pengawas juga berperan penting dalam pengelolaan Perumda karena merekalah yang mewakili Perumda. Direksi dan dewan pengawas harus mandiri dan independen dalam menjalankan tugasnya agar Perumda dapat dikelola dengan baik. Dalam menjalankan tugas, direksi dan dewan pengawas membutuhkan dukungan SDM yang handal yang dapat diperoleh melalui rekrutmen yang dilakukan secara profesional dan sesuai dengan ketentuan peraturan perundang-undangan.

BUMD yang berbentuk Perseroda berorientasi pada keuntungan. Oleh karena itu dibutuhkan organ Perseroda yaitu direksi dan komisaris yang handal yang dapat mengelola Perseroda dengan baik sesuai dengan PP No. 56 Tahun 2017. Mengingat pentingnya direksi dan dewan komisaris sebagai organ Perseroda yang mewakili Perseroda maka rekrutmen direksi dan komisaris harus dilakukan dengan baik, sesuai dengan ketentuan peraturan perundangundangan yang berlaku. Pada Perseroda, kepala daerah yang berkedudukan sebagai pemegang saham mayoritas, memiliki kewenangan mengambil keputusan. Implikasinya kepala daerah memiliki peran penting dalam pengelolaan Perseroda sehingga visi, misi kepala daerah juga berpengaruh pada perkembangan Perseroda. Pelaksanaan kewenangan kepala 
daerah tersebut tidak boleh merugikan pemegang saham minoritas yang mendapat pelindungan hukum dalam UU No. 40 Tahun 2007.

Bentuk hukum BUMD berimplikasi pada pengelolaan BUMD baik yang berbentuk Perumda maupun Perseroda. Agar BUMD dapat dikelola dan berkembang dengan baik maka:

1. Kepala daerah yang memiliki kewenangan cukup besar untuk mengambil keputusan baik pada Perumda maupun Perseroda harus memiliki visi, misi, niat baik, dan keseriusan untuk mengembangkan BUMD.

2. Direksi, dewan pengawas, komisaris, dan pegawai BUMD haruslah orang-orang yang berkualitas yang dapat menjalankan tugasnya dengan baik dalam pengelolaan BUMD. Untuk itu rekrutmen direksi, dewan pengawas, komisaris, dan pegawai BUMD harus dilakukan sesuai dengan ketentuan perundang-undangan yang berlaku.

3. Direksi, dewan pengawas, dan komisaris harus independen dan mandiri dalam menjalankan tugasnya sehingga BUMD dapat dikelola dengan baik. Untuk itu tidak boleh ada paksaan dan ancaman dari siapa pun dan dalam bentuk apa pun terhadap direksi, dewan pengawas, dan komisaris yang tidak sesuai dengan ketentuan peraturan perundang-undangan.

\section{DAFTAR PUSTAKA}

\section{Jurnal}

Bako, Ronny Sautma Hotma. "Permasalahan Hukum Atas Bentuk Badan Hukum pada Badan Usaha Milik Daerah”. Kajian. Vol.15 No.4, 2010, https:/jurnal.dpr.go.id/ index.php/kajian/article/view/589. Diakses tanggal 29 Januari 2018.
Budhisulistyawati, Ambar; Yudho Taruno Muryanto; dan Anjar Sri CN. "Strategi Pengelolaan Badan Usaha Milik Daerah (BUMD) Persero untuk Mewujudkan Prinsip Tata Kelola Perusahaan yang Baik". Privat Law. Vol. III. No. 2. JuliDesember 2015. https://media.neliti.com/ media/publications/164361-ID-strategipengelolaan-badan-usaha-milik-d.pdf. Diakses tanggal 9 Januari 2018.

Harefa, Mandala. "Pengelolaan BUMD/ Perusahaan Daerah di Provnsi Sumatera Barat Nusa Tenggara Barat dan Kalimantan Selatan." Kajian. Vol. 15 No. 2. Juni 2010.

Kusumo, Dhimas Tetuko; Munawar Kholis, dan AL. Sentot Sudarwanto. "Kajian yuridis Bentuk Hukum Badan Usaha Milik Daerah (BUMD) di Bidang Perbankan Pasca Berlakunya Undang-Undang Nomor 23 Tahun 2014 tentang Pemerintah Daerah". Privat Law. Vol. IV. No. 1. Januari-Juni 2016. https://media.neliti.com/media/ publications/164480-ID-kajian-yuridisbentuk-hukum-badan-usaha.pdf. Diakses tanggal 3 Juni 2018.

Mardjana, I Ketut. "Corporate Governance dan Privatisasi." Jurnal Reformasi Ekonomi. Vol. 1. No. 2. Oktober-Desember 2002.

Muryanto, Yudho Taruno dan Djuwityastuti. "Model Pengelolaan Badan Usaha Milik Daerah (BUMD) dalam Rangka Mewujudkan Good Corporate Governance". Yustisia. Vol.3. No.1. Januari-April 2014. https://jurnal. uns.ac.id/yustisia/article/view/10136/9044. Diakses tanggal 2 Mei 2017.

Resen, Made Gde Subha Karma dan Yudho Taruno Muryanto, "Implikasi Yuridis Diundangkannya Undang-Undang Nomor 23 Tahun 2014 tentang Pemerintahan Daerah terhadap Pengaturan Badan Usaha Milik Daerah di Indonesia”. Yustisia. Vol.3. No.3. Edisi 90 September-Desember 2014. www.portalgaruda.org. Diakses tanggal 5 Juni 2018. 
Saefuloh, Asep Ahmad. "Kebijakan Pengelolaan Sumber Daya Manusia pada Badan Usaha Milik Daerah: Studi Kasus di Provinsi Sumatera Barat, Nusa Tenggara Barat dan Kalimantan Selatan”. Kajian. Vol. 15 No. 10, Maret 2010.

Sari, Maya, Abdul Rachmad Budiono dan Hanif Nur Widhiyanti. "Perlindungan Hukum Bagi Pemegang Saham Minoritas Yang tidak dilibatkan dalam Proses Akuisisi." Yuridika. Vol.32. No.3. September 2017. www.e-jounal.unair.ac.id/YDK/arcticle/ view/4827/pdf 2. Diakses tanggal 18 Mei 2018.

Sjawie, Hasbullah F. "Tanggung Jawab Direksi Perseroan Terbatas Atas Tindakan Ultra Vires". Jurnal Hukum Prioris. Vol. 6 No. 1. Tahun 2017. https://media.neliti.com/ media/publications/82266-ID-tanggungjawab-direksi-perseroan-terbata.pdf. Diakses tanggal 18 Mei 2018.

\section{Buku}

Asikin, H. Zainal dan L. Wira Pria Suhartana. Pengantar Hukum Perusahaan. Cetakan ke-1. Jakarta: Prenadamedia Group. 2016.

Cahyaningrum, Dian. "Perlindungan Konsumen dalam Transaksi Elektronik (E-Commerce) dalam Kerangka Masyarakat Ekonomi ASEAN" dalam Pembangunan Hukum dan Kebijakan Publik dalam Rangka Menyongsong Masyarakat Ekonomi ASEAN. Jakarta: P3DI Setjen DPR RI dan Azza Grafika. 2015.

Fuady, Munir. Perseroan Terbatas Paradigma Baru. Bandung: Citra Aditya Bakti. 2003.

Garner, Bryan A. Black's Law Dictionary. Eight Edition. St. Paul: Thomson West. 2004.

Kansil, C.S.T. dan Christine S.T.Kansil. Seluk Beluk Perseroan Terbatas Menurut UndangUndang No. 40 Tahun 2007. Jakarta: Rineka Cipta. 2009.

Muhammad, Abdulkadir. Hukum Perusahaan Indonesia. Bandung: Citra Aditya Bakti. 2010.
Pemerintah Provinsi Jawa Timur. Kondisi Keungan Perusda Jatim Periode 31 Desember 2016. Surabaya: Biro Administrasi Perekonomian Pemerintah Provinsi Jawa Timur. 2017.

Simatupang, Richard Burton. Aspek Hukum dalam Bisnis. Edisi Revisi. Jakarta: Rineka Cipta. 2007.

Surya, Indra dan Ivan Yustiavandana. Penerapan Good Corporate Governance Mengesampingkan Hak-Hak Istimewa Demi Kelangsungan Usaha. Jakarta: Prenada Media Group. 2006.

Tobing, Rudyanti Dorotea. Aspek-Aspek Hukum Bisnis Pengertian, Asas, Teori, dan Praktik. Surabaya: LeksBang Justitia. 2015.

Usman, Rachmadi. Dimensi Hukum Perusahaan Perseroan Terbatas. Bandung: PT. Alumni. 2004.

Widjaja, Gunawan. Tanggung Jawab Direksi atas Kepailitan Perseroan. Jakarta: RajaGrafindo Persada. 2005.

\section{Pustaka dalam Jaringan}

Himawan, Aditya. "Kontribusi BUMD Masih Minim”. 28 Oktober 2015. http://www. suara.com/bisnis/2015/10/28/181655/ kontribusi-bumd-masih-minim. Diakses tanggal 20 April 2017.

Hidayat, Avit. 17 Desember 2014. "1360 BUMD Se-Indonesia Tidak Sehat”, http:// www.enciety.co/1360-bumd-se-indonesiatidak-sehat/. Diakses tanggal 20 April 2017.

Komite Nasional Kebijakan Governance. "Pengertian Good Corporate Governance". http://muc-advisory.com/tag/komitenasional-kebijakan-governance-knkg/mucadvisory.com. Diakses tanggal 17 April 2018.

WartaEkonomi. 8 Februari2016. "DPD: Banyak Masalah di BUMN dan BUMD".https:// www.wartaekonomi.co.id/read89666/dpdbanyak-masalah-di-bumn-dan-bumd.html. Diakses tanggal 21 April 2017. 
Riyandi, Rizma dan Budi Raharjo. 11 April 2017.

"Pengamat: Jumlah BUMD Sakit Lebih Banyak Dibanding yang Sehat". http:// www.republika.co.id/berita/koran/dialogjumat/15/01/02/ekonomi/makro/17/04/10/ oo733f415-pengamat-jumlah-bumdsakit-lebih-banyak-dibanding-yang-sehat. Diakses tanggal 20 April 2017. 